\title{
SUPERVISI KEPALA SEKOLAH UNTUK MENINGKATKAN KOMPETENSI PEDAGOGIK SPIRITUAL PENDIDIK
}

\author{
Nurti Budiyanti, Asep Abdul Aziz, Dikdik Sunandar, Mohamad Erihadiana \\ ${ }^{1}$ Universitas Pendidikan Indonesia (UPI) Bandung, Indonesia \\ ${ }^{2,3,4}$ UIN Sunan Gunung Djati Bandung, Indonesia \\ Email: nurtibudiyanti@upi.edu
}

\begin{abstract}
The welfare of a nation is determined by the quality of education. Similarly, the quality of education is determined by the quality of teacher competencies, especially spiritual pedagogical competencies. The development of the spiritual pedagogical competence of teachers in Islamic boarding schools is a must, considering the teacher as the spearhead in determining the processes and learning outcomes. Likewise, principals as a supervisor has a strategic role in making use of teachers in school. This study focuses on analyzing the approaches, strategies, and implications of the principal's supervision as a means of improving the spiritual pedagogical competence of teachers in PPI 1-2 Bandung. In addition, this study also employed a qualitative approach in the form of case study. The data were taken from documentation and informants determined by snowball sampling. The data were collected using interviews, observation, and study documentation. The data were analyzed through reducing data, presenting data, and drawing conclusions. Then, the data were validated by triangulating the sources. The results of this study are that (1) Principal supervision strategy is carried out through the effective application of academic supervision with conceptual, interpersonal and technical skills. (2) The principal's supervision approach uses a direct, indirect and collaborative approach. In this case, what is studied is related to mastering learning theory and learning principles that educate, developing curriculum related to the subjects being taught, and utilizing information and communication technology in learning that is taught. (3) The implications for schools are the creation of a conducive school atmosphere and effective learning by updating the character of the curriculum, policies and rules that contain spiritual values. Then, the implication for teachers is the creation of a conducive school atmosphere and effective learning by disciplining administration, expanding resources and teaching materials, utilizing technology and information, applying the Quranic method, applying educational media, and establishing an evaluation and enrichment program that functions to improve spiritual quality of students. Thus, the improvement of teacher spiritual pedagogical competence can be applied well in order to produce students who have Islamic character.
\end{abstract}

Keywords: Supervision; spiritual pedagogical competence; teacher.

\begin{abstract}
ABSTRAK
Kesejahteraan suatu bangsa ditentukan oleh kualitas pendidikan. Kualitas pendidikan ditentukan oleh kualitas kompetensi pendidik, khususnya kompetensi pedagogik spiritual. Pengembangan kompetensi pedagogik spiritual pendidik di pesantren merupakan suatu keharusan, mengingat pendidik sebagai ujung tombak dalam menentukan proses dan hasil pembelajaran. Begitupun dengan kepala sekolah sebagai supervisor yang memiliki peran strategis dalam mendayagunakan para pendidik di sekolah. Fokus penelitian ini untuk menganalisis bagaimana pendekatan, strategi dan implikasi supervisi kepala sekolah untuk meningkatkan kompetensi pedagogik spiritual pendidik di PPI 1-2 Bandung. Jenis penelitian ini ialah penelitian kualitatif dengan jenis studi kasus. Data bersumber dari dokumentasi dan informan yang ditetapkan secara snowball sampling. Teknik pengumpulan data menggunakan wawancara, observasi, dan studi dokumentasi. Analisis data dengan mereduksi data, penyajian data kemudian penarikan kesimpulan. Pengecekan
\end{abstract}


keabsaan data dilakukan dengan triangulasi sumber. Hasil dari penelitian ini ialah (1) Strategi supervisi kepala sekolah melalui penerapan supervisi akademik secara efektif dengan keterampilan konseptual, interpersonal dan tehnik. (2) Pendekatan supervisi kepala sekolah menggunakan pendekatan langsung, tidak langsung dan kolaboratif. Dalam hal ini yang diteliti berkaitan dengan menguasai teori belajar dan prinsip-prinsip pembelajaran yang mendidik, mengembangkan kurikulum yang terkait dengan mata pelajaran yang diampu, serta memanfaatkan teknologi informasi dan komunikasi dalam pembelajaran yang diampu. (3) Implikasi bagi sekolah yakni terciptanya suasana sekolah yang kondusif dan pembelajaran yang efektif dengan memperbaharui karakter kurikulum, kebijakan serta aturan yang mengandung nilai-nilai spiritual. Kemudian implikasi bagi pendidik ialah terciptanya suasana sekolah yang kondusif dan pembelajaran yang efektif dengan mendisiplinkan administrasi, memperluas sumber dan bahan ajar, memanfaatkan teknologi dan informasi, menerapkan metode qur'ani, menerapkan media edukatif, membat program evaluasi dan pengayaan yang berfungsi untuk meningkatkan kulitas spiritual peserta didik. Dengan demikian peningkatan kompetensi pedagogik spiritual pendidik mampu diaplikasikan dengan baik untuk menghasilkan peserta didik yang berkarakter Islami.

Kata Kunci: Kompetensi pedagogik spiritual; supervisi; pendidik.

\section{PENDAHULUAN}

Salah satu kompenen penting dari sistem pendidikan yaitu pendidik, karena pendidik merupakan komponen pendidikan yang bersentuhan langsung dengan peserta didik. Baik buruknya hasil dari sebuah proses pembelajaran sangat ditentukan oleh kemampuan pendidik dalam mengelola proses pembelajaran. Untuk dapat melaksanakan tugas dan tanggung jawabnya, maka seorang pendidik harus memiliki sejumlah kompetensi yang berkaitan dengan pengembangan pengetahuan, sikap, dan keterampilan. Menurut Saiful Sagala kompetensi adalah perpaduan dari penguasaan, pengetahuan, keterampilan, nilai dan sikap yang direfleksikan dalam kebiasaan berfikir dan bertindak dalam melaksanakan tugas dan pekerjaannya. Dalam hal ini, kompetensi yang harus dimiliki seorang pendidik mencangkup kompetensi pedagogik, kompetensi kepribadian, kompetensi sosial dan kompetensi professional (Victorynie, 2018).

Dalam peraturan menteri Pendidikan Nasional No. 16 tahun 2007 dijelaskan tentang kompetensi pedagogik pendidik. Khusus pada kompetensi pendidik dijelaskan sebagai berikut (Tim Redaksi Nuansa Aulia, 2008): (1) Menguasai karakteristik peserta didik dari aspek fisik, moral, social, kultural, emosional dan intelektual; (2) Menguasai teori belajar dan prinsip-prinsip pembelajaran yang mendidik; (3) Menguasai teori belajar dan prinsip-prinsip pembelajaran yang mendidik; (4) Menyelenggarakan pembelajaran yang mendidik; (5) Memanfaatkan teknologi informasi dan komunikasi untuk kepentingan pembelajaran; (6) Memfasilitasi pengembangan potensi peserta didik untuk mengaktualisasikan berbagai potensi yang dimiliki; (7) Berkomunikasi secara efektif, empatik dan santun dengan peserta didik; (8) Menyelenggarakan penilaian dan 
evaluasi proses dan hasil belajar; (9) Memanfaatkan hasil penilaian dan evaluasi untuk kepentingan pembelajaran; (10) Melakukan tindakan reflektif untuk peningkatan kualitas pembelajaran.

Fenomena akhir ini muncul praktik pendidikan yang berlandaskan nilai-nilai spiritual. Kecenderungan ini melahirkan bidang kajian baru yang dikenal dengan pedagogik spiritual. Dalam pendekatan ini pendidikan dan pembelajaran dilaksanakan oleh pendidik dengan berlandaskan pada nilai yang dijadikan panduan dalam menjalankan profesinya seperti nilai kasing sayang, kesabaran, kerendahan hati, kepekaan, toleransi, dan nilai-nilai lainnya. Pemahaman tentang spiritualitas ini sangat penting dalam membina generasi millennium, sehingga pendidik perlu terus dibina agar mampu menyesuaikan pengetahuan dan keterampilannya dengan kebutuhan dunia kontemporer (Syihabuddin, 2016).

Agar pendidik mampu menerapkan nilai-nilai spiritual dalam kegiatan pembelajaran di kelas, Jacobs Shimabukuro mengemukakan karakteristik pendidik dalam pembelajaran berwawasan spiritual yakni (Kaffah \& Prayoga, 2019; Prayoga \& Irawan, 2020): (1) Pendidik memahami perkembangan jiwa dan pengalaman spiritual anak (2) Pendidik mengambil sikap kontemplatif (3) Pendidik menunjukkan spirit murah hati (4) Pendidik memiliki kepekaan interpersonal dalam melaksanakan profesinya (5) Pendidik melakukan berbagai kegiatan dengan semangat terutama dalam mengajar. Nilai-nilai spiritual ini mampu mengubah praktif mengjar pendidik menjadi lebih efektif, dan mendorong para pendidik untuk bertindak lebih dapat menerima berbagai keadaan siswa, lebih perhatian dan lebih hangat.

Untuk mengembangkan kompetensi tersebut seorang pendidik membutuhkan bantuan berupa bimbingan yang terencana dari seorang supervisor. Suhartian mengatakan bahwa supervisi bertujuan memberikan layanan dan bantuan untuk meningkatkan kualitas belajar mengajar di kelas untuk menghasilkan kualitas belajar yang baik (Suhertian, 2008). Menurut Peraturan Pendidikan Nasional nomor 13 tahun 2007 tentang kompetensi supervisi kepala sekolah yaitu (Tim Redaksi Nuansa Aulia, 2008): (1) Merencanakan program supervisi akademik dalam rangka meningkatkan profesionalisme pendidik. (2) Melaksanakan supervisi akademik terhadap pendidik dengan menggunakan pendekatan dan teknik supervisi yang tepat. (3) Menindak lanjuti supervisi akademik terhadap pendidik dalam rangka peningkatan profesionalisme pendidik. E Mulyasa pun menegaskan bahwa untuk mengetahui sejauh mana pendidik mampu melaksanakan pembelajaran secara berkala, kepala sekolah perlu melaksanakan kegiatan supervisi, yang dapat dilakukan 
melalui kegiatan kunjungan kelas untuk mengamati proses pembelajaran secara langsung, terutama dalam penilaian dan penggunaan metode, media yang digunakan dan keterlibatan siswa dalam proses pembelajaran. Dari hasil supervisi ini, dapat diketahui kelemahan sekaligus keunggulan pendidik dalam melakukan pembelajaran, tingkat penguasaan kompetensi pendidik yang bersangkutan, selanjutnya diupayakan solusi, pembinaan dan tindak lanjut tertentu sehingga pendidik dapat memperbaiki kekurangan yang ada sekaligus mempertahankan keungggulannya dalam melaksanakan pembelajaran. Kepala sekolah memiliki peran strategi untuk meningkatkan mutu pendidikan di lembaga yang dipimpinnya. Kepala sekolah tidak saja berperan sebagai pemimpin pembelajaran, tetapi lebih dari itu ia merupakan pemimpin keseluruhan fungsi-fungsi kepemimpinan dalam suatu sekolah seperti perencanaan, pembinaan karir, koordinasi dan evaluasi (Baharuddin, 2016).

Pesantren Persatuan Islam 1-2 Bandung adalah salah satu sekolah yang ada di Kota Bandung yang melaksanakan kegiatan supervisi. Bimbingan seorang supervisor benar-benar dibutuhkan oleh para pendidik untuk meningkatkan kompetensi mereka, demi terwujudnya pelaksanaan proses belajar mengajar yang lebih baik di sekolah tersebut. Supervise adalah suatu aktivitas pembinaan yang terencana untuk membantu para pendidik dan pegawai sekolah lainnya dalam melakukan pekerjaan mereka secara efektif (Purwanto, 1984). Adapun yang menjadi fokus kajian dalam penelitian ini adalah; (1) Pendekatan kepala sekolah untuk meningkatkan kompetensi pedagogic spiritual pendidik di PPI 1-2 Bandung. (2) Strategi kepala sekolah untuk meningkatkan kompetensi pedagogik spiritual pendidik di PPI 1-2 Bandung. (3) Bagaimana implikasi penerapan supervise kepala sekolah terhadap peningkatan kompetensi pedagogik spiritual pendidik di PPI 12 Bandung.

\section{METODE}

Penelitian ini menggunakan metode kualitatif. Karena penelitian ini berusaha mengungkapkan gejala suatu tradisi tertentu yang secara fundamental tergantung pada pengamatan manusia dalam kawasannya sendiri dan berhubungan dengan orang-orang tersebut dalam bahasannya dan peristilahannya, sebagaimana pendapat Kirk dan Miller (Moleong, 2012). Data yang dikumpulkan dari latar yang alami (natural setting) sebagai sumber data langsung. Adapun objek penelitiannya ialah. Penelitian ini dilaksanakan di Pesantren Persatuan Islam 1-2 Bandung Jl. Pajagalan No.1416, Karanganyar, Kec. Astana Anyar, Kota Bandung, Jawa Barat 40241, Indonesia. 
Sumber data primer adalah data yang diperoleh peneliti secara langsung dari tangan pertama yaitu: Kepala Sekolah dan Tenaga pendidik. Sedangkan sumber data sekunder yaitu data yang diperoleh peneliti dari sumber yang sudah ada seperti: dokumentasi pelaksanaan supervisi di PPI 1-2 Bandung, visi dan misi, serta tujuan sekolah dan struktur organisasi. Metode pengumpulan data meliputi; metode observasi, sebagai pengamatan dan pencatatan dengan sistematik atas fenomena-fenomena yang diteliti (Hadi and Andi, 2004). Observasi sebagai alat untuk mengumpulkan data tingkah laku kepala sekolah dalam melaksanakan supervisi ataupun proses terjadinya kegiatan pelaksanaan supervisi (Ibrahim, 2001). Metode wawancara, pengumpulan data melalui proses tanya jawab lisan yang berlangsung satu arah, antara peneliti kepala sekolah, tenaga pendidik dan kependidikan dan sivitas akademik PPI 1-2 Bandung lainnya (Fathoni, 2006). Metode dokumentasi, menyelidiki benda-benda tertulis seperti buku, majalah, dokumen, peraturan-peraturan madrasah, notulen rapat, catatan harian dan lain-lain (Arikunto, 2003).

Dalam pengujian keabsahan data, penelitian ini menggunakan teknik triangulasi, dengan meninjau kebenaran data tertentu dengan data yang diperoleh (Arikunto, 2003); kecukupan referensial, teknik pengujian keabsahan data dengan cara melengkapi pengumpulan data dengan perekam suara, kamera foto, dan kamera video (Buckley \& Irawan, 2015). Teknik analisis data sebagai upaya mencari dan menata secara sistematis catatan hasil observasi, wawancara, dan lainnya sebagainya untuk meningkatkan dan memahamkan peneliti tentang supervisi kepala sekolah di PPI 1-2 Bandung (Tohirin, 2012).

\section{PEMBAHASAN}

\section{Pendekatan Kepala Sekolah Untuk Meningkatkan Kompetensi Spiritual Pedagogik Pendidik}

Pendekatan seorang kepala sekolah terhadap pendidik dalam sebuah pembinaan sangatlah diperlukan dalam menentukan proses dan hasil pembelajaran. Pendekatan yang digunakan dalam menerapkan supervisi pendidikan sering didasarkan pada prinsip prinsip psikologis. Suatu pendekatan supervisi pendidikan sangat bergantung pada prototyp pendidik. Adapun secara teoritis, Glickman dalam Sahertian mengungkapkan beberapa pendekatan yang dapat digunakan supervisor dalam melakukan supervise yaitu (Piet, 2010): (1) pendekatan langsung/direktif approach. (2) pendekatan tidak langsung/non direktif approach. (3) dan pendekatan kolaboratif/ collaborative approach. 
Dalam hal ini yang dilakukan oleh kepala sekolah untuk meningkatkan kompetensi pedagogik spiritual pendidik di PPI 1-2 Bandung ialah sebagai berikut: (1) Pendekatan langsung (direktif approach), pendekatan ini dilakukan terhadap pendidik yang mengalami kekurangan ilmu dan pengalaman, sehingga kepala sekolah memberikan arahan, bimbingan, penjelasan, memberikan contoh, menetapkan tolak ukur, memberikan penguatan dan motivasi untuk kembali membangun kompetensi pedagogik spiritual pendidik. (2) Pendekatan tak langsung (non direktif approach), pendekatan ini dilakukan oleh kepala sekolah untuk membina pendidik yang sedang mengalami permasalahan. Jika ada permasalahan yang terjadi, kepala sekolah mencari info kepada beberapa informan yang kemudian dicarikan solusi terbaik, agar permasalahan tidak berkepanjangan dan tidak menghambat aktivitas belajar mengajar. (3) Pendekatan kolaboratif (collaborative approach), pendekatan ini digunakan oleh kepala sekolah untuk membangun komitmen bersama untuk memajukan pendidikan, seperti terbentuknya kegiatan KKG di internal sekolah yang rutin diadakan setiap hari sabtu.

Upaya yang dilakukan kepala sekolah dalam melakukan supervisi itu dapat berjalan dengan baik dan lancar, berkat kemampuan manajerial yang dimiliki kepala sekolah yang selalu membina komunikasi yang baik dengan para pendidik. Asumsi ini berdasar pada suatu fenomena yang mana kepala sekolah selalu melibatkan para pendidik dalam pembuatan program supervisi, sosialisasi program dan jadwal agenda kegiatan pendidik yang selalu dipublikasikan secara merata. Para pendidik selalu memberikan sikap yang positif dalam pengayaan program supervisi ini, karena dampaknya memberikan banyak manfaat serta perbaikan yang signifikan.

Dalam hal membina hubungan antar sesama Allah menegaskan melalui firman-Nya :

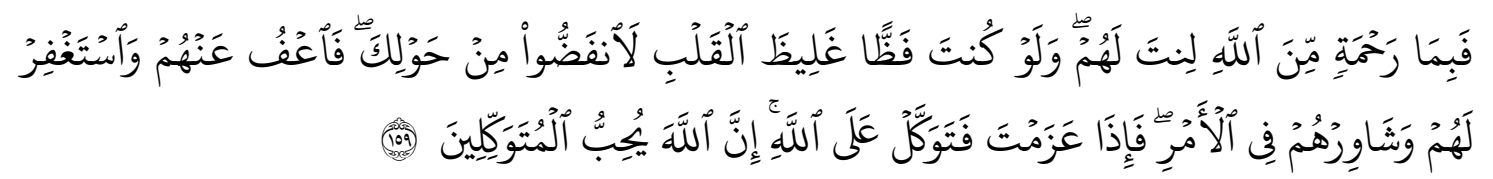

"Maka berkat rahmat Allah engkau (Muhammad) berlaku lemah lembut terhadap mereka. Sekiranya engkau bersikap keras dan berhati kasar, tentulah mereka menjauhkan diri dari sekitarmu. Karena itu maafkanlah mereka dan mohonkanlah ampunan untuk mereka, dan bermusyawarahlah dengan mereka dalam urusan itu. Kemudian, apabila engkau telah membulatkan tekad, maka bertawakallah kepada Allah. Sungguh, Allah mencintai orang yang bertawakal (Q.S. Al-Imran [3]: 159).

Analisis penulis berkaitan dengan hal ini, hubungan harmonis baik diantara kepala sekolah dengan pendidik, maupun pendidik dengan muridnya sangatlah diperlukan, hubungan yang 
harmonis mampu membuat pelaksanaan supervisi berjalan dengan lancar, memecahkan semua persoalan kependidikan dan mampu menjadi bahan perbekalan untuk perbaikan di masa mendatang. Pendekatan demokratis di rasa paling tepat untuk diterapkan di semua lembaga pendidikan. Dengan pendekatan ini, mampu memunculkan ikatan jalinan kesepakatan untuk mencapai visi misi serta tujuan dari suatu lembaga pendidikan sehingga pendidik melakukan proses pembelajaran berdasarkan pada nilai-nilai spiritual, seperti nilai kasing sayang, kesabaran, kerendahan hati, kepekaan, toleransi, dan nilai-nilai lainnya. Pemahaman tentang spiritualitas ini sangat penting dalam membina generasi millennium, sehingga pendidik perlu terus dibina agar mampu menyesuaikan pengetahuan dan keterampilannya dengan kebutuhan dunia kontemporer. Sebagaimana yang pernah diunggapkan oleh Sanusi sejatinya pendidikan dimaksudkan untuk meningkatkan potensi spiritual peserta didik (Sanusi, 2013).

\section{Strategi Kepala Sekolah Untuk Meningkatkan Kompetensi Spiritual Pedagogik Pendidik}

Strategi adalah upaya atau usaha yang terencana secara detail untuk mencapai suatu rencana yang telah ditentukan. Glueck mendefinisikan strategi sebagai suatu kesatuan rencana yang komprehensif dan terpadu yang menggabungkan kekuatan organisasi dengan lingkungan yang dihadapinya, kesemuanya menjamin agar tujuan organisasi tercapai. Menurut Kartz sebagimana yang dikutip oleh Sudarwan Danim bahwa kemampuan manajerial itu meliputi technical skill (kemampuan teknik), humam skill (kemampuan hubungan kemanusiaan), dan conceptual skill (kemampuan konseptual). Sepadan dengan hal itu, Glikcman berpendapat bahwa untuk melaksanakan supervisi akademik secara efektif diperlukan keterampilan konseptual, interpersonal, dan tehnikal (Danim, 2002; Gluek \& William, 1998; Prasojo \& Sudiyono, 2011).

Proses pengawasan pada dasarnya dilaksanakan oleh administrasi dan manajemen dengan mempergunakan dua macam teknnik, yaitu (Sondang P, 2015): (1) pengawasan langsung/direct control (2) pengawasan tidak langsung/ indirect control. Sedangkan menurut Gwyn, teknik-teknik supervisi akademik itu meliputi dua macam yakni individual dan kelompok (Prasojo \& Sudiyono, 2011). Berkaitan dengan hal ini, ada beberapa usaha yang dilakukan oleh kepala sekolah dalam memperbaiki dan mengembangkan kompetensi pedagogik spiritual pendidik di sekolah, baik yang bersifat internal maupun eksternal, yakni sebagai berikut : (1) Mengikuti Bimbingan Teknik (Bimtek) dan Pelatihan : Kegiatan bimbingan teknis dan pelatihan ini bersifat eksternal, artinya para pendidik hanya ikut serta dalam suatu kegiatan yang di dalamnya bertujuan untuk menambah pengetahuan dan mempertajam pemikiran. Sebagaimana Azyumardi (Azra, 1999) menegaskan 
bahawa kaum muslimin hendaknya menggunakan dan mengembangkan akal fikirannya sesuai dengan anjuran dan perintah Allah dalam Qs. Al-Zumar ayat 9. Pelatihan menurut Oemar H.M mempunyai manfaat yang amat besar karena suatu pelatihan tidak saja memberikan pengalaman baru tetapi juga berfungsi mengembangkan kemampuan berfikir guna memecahkan masalahmasalah yang dihadapi dalam rangka memperlancar transfer belajar (Hamalik, 1994). (2) Kelompok Diskusi Pendidik: Lembaga pendidikan PPI 1-2 Bandung mengadakan program upaya pengembangan kurikulum atau silabus melalui kegiatan diskusi pendidik. Kelompok diskusi pendidik ini dilakukan dengan pendidik satu rumpun kelas atau mata pelajaran yang sudah berjalan selama puluhan tahun dengan baik dan terorganisir dilaksanakan setiap hari ahad. Kegiatan ini membahas tentang perangkat pembelajaran (program tahunan, program semester, rencana pelaksanaan pembelajaran), kesamaan materi pelajaran dan pengembangannya, pembuatan kisikisi soal dan soal ulangan, alat peraga, program remedial, program pengayaan, program pembinaan santri, program unggulan sekolah dan sharing tentang masalah yang muncul dalam proses pembelajaran. (3) Kelompok Kerja Pendidik $(K K G)$ : Kegiatan KKG ini bersifat wajib, harus diikuti oleh seluruh pendidik. Kegiatan ini dimaksudkan agar pendidik dapat bertanggungjawab terhadap pelaksanaan dan hasil pembelajaran. Menurut (Mulyasa, 2013) dengan MGMP, dan KKG dapat dipikirkan bagaimana menyiasati padatnya kurikulum, memecahkan persoalan dan masalah yang dihadapi oleh pendidik dalam pembelajaran dan mencari alternative pembelajaran yang tepat serta dapat menemukan berbagai variasi metode dan media pembelajaran. Adapun manfaat yang dirasakan oleh para pendidik terhadap pengayaan kegiatan KKG ini ialah : dapat memupuk kesadaran akan pentingnya peningkatan kemampuan sebagai pendidik, dapat saling membelajarkan, dapat membina rasa kekeluargaan, dapat memberikan inovasi dan kreatifitas dalam mengelola kegiatan belajar mengajar. Oleh karena itu, kegiatan yang dilakukan dan masalah yang dibahas dalam KKG hendaknya bersumber dari kebutuhan pendidik, terutama dalam hubungannya dengan kegiatan belajar mengajar dan menekankan prinsip musyawarah, sesuai dengan firman Allah dalam Qs. Asy-Syura ayat 38. (4) Mengadakan Kajian Bulanan : Kajian bulanan ini diselenggarakan oleh pihak yayasan. Program ini dimaksudkan agar seluruh elemen baik pendidik, murid, pegawai dan masyarakat yang berada di sekitar wilayah PPI 1-2 Bandung memiliki himmah yang kuat untuk berthalabul ilmi dalam rangka pembinaan aspek rohani, sehingga mampu mengingatkan kembali nilai-nilai spiritual yang harus diaplikasikan dalam kehidupan sehari-hari. Hal ini sesuai denhgan firman Allah dalam Qs. Al-Mujadallah ayat 11 yang 
berkaiatan dengan perintah untuk mengunjungi majelis ilmu. (5) Melakukan Supervisi : Pengawasan pada satuan pendidikan dilaksanakan oleh kepala sekolah sebagai pimpinan intern sekolah. Fungsi supervisi harus dioptimalkan karena menentukan keberhasilan program. Teknik supervisi pendidikan dapat digunakan dalam membantu pendidik-pendidik meningkatkan situasi belajar mengajar, baik secara kelompok, maupun secara perorangan, baik dengan cara langsung/bertatap muka dan cara tak langsung melalui media komunikasi (visual, audio, audio visual) (Engkoswara \& Komariah, 2010). Cara demikianlah yang sering diterapkan oleh kepala sekolah untuk memantau apa yang perlu diperhatikan dan perlu dipertimbangkan dalam melakukan supervisi.

Strategi supervisi yang dilakukan di sekolah PPI 1-2 Bandung lebih ditekankan pada pengawasan administrasi pendidik, khususnya yang berkaitan dengan kelengkapan perencanaan pembelajaran, pelaksanaan pembelajaran dan evaluasi pembelajaran. Kesimpulannya, apa yang dilakukan oleh kepala sekolah sudah mengacu pada kompetensi manajerial kepala sekolah yakni: melakuikan monitoring, evaluasi, dan pelaporan pelaksanaan program kegiatan sekolah dengan prosedur yang tepat serta merencanakan tindak lanjutnya. Asusmi penulis, strategi yang dilakukan oleh kepala sekolah dalam rangka proses evaluasi tersebut merupakan hal yang sangat penting dilakukan, sebab manusia ialah makhluk yang lemah. Hal ini termaktub dalam firman Allah dalam Qs. An-Nisa ayat 28, Qs. An-Naml ayat 78, dan Qs. Al-Isra ayat 89, yang mana setiap manusia perlu ada yang mengingatkan untuk mencapai perbaikan di kemudian hari.

\section{Implikasi penerapan Supervisi Kepala Sekolah Terhadap Peningkatan Kompetensi Spiritual Pedagogik Pendidik}

Berdasarkan Peraturan Menteri Pendidikan Nasional nomor 13 tahun 2007 tentang kompetensi supervisi kepala sekolah adalah; (1) Merencanakan program supervisi akademik dalam rangka meningkatkan profesionalisme pendidik (2) Melaksanakan supervisi akademik terhadap pendidik dengan menggunakan pendekatan dan teknik supervisi yang tepat (3) Menindak lanjuti supervisi akademik terhadap pendidik dalam rangka peningkatan profesionalisme pendidik (Tim Redaksi Nuansa Aulia, 2008). Berkaitan dengan hal tersebut, strategi kepala sekolah dalam mengembangkan kompetensi pedagogik spiritual yang dilaksanakan di PPI 1-2 Bandung memiliki dampak yang signifikan bagi pendidik dan PPI 1-2 Bandung sebagai lembaga untuk ditindak lanjuti. 
Hal tersebut dilihat dari beberapa aspek, yang akan divisualisasikan ke dalam bentuk bagan berikut:

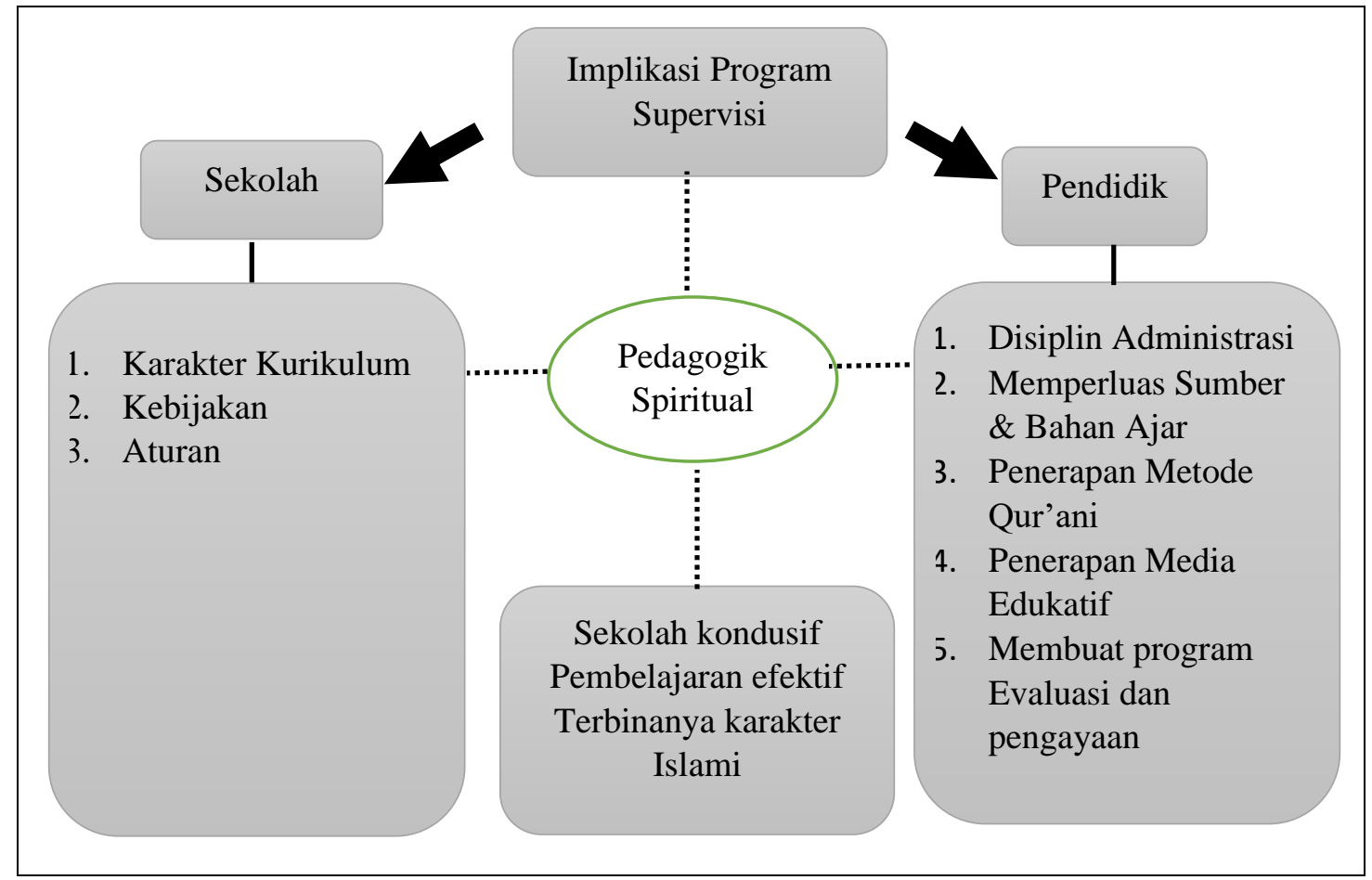

Berdasarkan bagan tersebut, beberapa implikasi bagi sekolah ialah : (1) Karakter kurikulum : berdasarkan hasil tindak lanjut dari program supervisi ini, kepala sekolah dapat menambahkan dan memperbaharui kurikulum lembaga dengan menyisipkan pendidikan spiritual untuk kembali menumbuhkan nilai-nilai islami, seperti nilai kasing sayang, kesabaran, keikhlasan, kerendahan hati, kepekaan, toleransi, dan nilai-nilai lainnya di lingkungan pendidikan. Sebagaimana para pakar pendidikan seperti Syahidin mengungkapkan ada 4 karakter yang harus dimuat dalam sebuah kurikulum pendidikan Islam, diantaranya ialah iman, ilmu, amal dan akhlak. (2) Penerapan Kebijakan: berdasarkan hasil tindak lanjut dari program supervisi ini, kepala sekolah menerapkan kebijakan-kebijakan untuk pendidik yang berprestasi. Kebijakan ini berupa fasilitas bahkan ada yang sampai di umrohkan (Prayoga \& Supiana, 2020; Sahmudin \& Prayoga, 2019). Kebijakan ini berfungsi untuk memotivasi para pendidik untuk lebih semangat dan telaten dalam mendidik dan membelajarkan para siswanya di kelas maupun di luar kelas. (3) Penerapan Aturan: berdasarkan hasil tindak lanjut dari program supervisi ini, kepala sekolah menerapkan beberapa aturan tegas untuk seluruh pendidik, seperti mendisiplinkan kehadiran pendidik di ruang rapat, di ruang pembinaan dan di ruang kelas. Aturan ini berfungsi untuk meningkatkan profesionalisme pendidik, agar setiap langkah yang dilakukannya perlu dipertanggung jawabkan secara bijak. Asumsi penulis 
berkaitan dengan hal ini sudah cukup baik. Karena kompetensi manajerial kepala sekolah akan mempengaruhi kualitas kompetensi pendidik yang akan berdampak besar pada kualitas lulusan siswa di suatu lembaga pendidikan (Syahiddin, 2009).

Adapun implikasi bagi pendidik ialah (Dian \& Prayoga, 2019; Prayoga et al., 2020): (1) Disiplin Administrasi : berdasarkan hasil tindak lanjut dari program supervisi ini, pendidik dituntut untuk lebih disiplin lagi dalam mengarsipkan dan membuat dokumen-dokumen yang mendukung aktivitas pembelajaran. (2) Memperluas Sumber \& Bahan Ajar : berdasarkan hasil tindak lanjut dari program supervisi ini, pendidik dituntut untuk memperluas sumber dan bahan ajar dengan memanfaatkan kemajuan teknologi dan informasi di era 4.0 ini. Semakin luas sumber dan bahan ajar diharapkan materi semakin mendalam dan wawasan peserta didik semakin terbuka luas. Dalam hal ini, sumber pendidikan Islam memiliki fungsi yang sangat penting dan strategis. Sebagaimana (Nata, 2010) telah mengarahkan tujuan pendidikan Islam yang ingin dicapai, membingkai seluruh kurikulum yang dilakukan dalam proses belajar mengajar, yang didalamnya termasuk materi, metode, media, sarana, dan evaluasi, menjadi standar dan tolak ukur dalam evaluasi. (3) Penerapan Metode Qur'ani : berdasarkan hasil tindak lanjut dari program supervisi ini, pendidik dituntut untuk menerapkan metode pembelajaran berbasis qur'ani, karena dengan metode inilah nilai-nilai pedagogik spiritual akan mudah diterapkan dalam proses pembelajaran. Dalam hal ini banyak sekali metode yang dapat digunakan dalam proses pembelajaran sebagaimana yang telah dikaji oleh Syahidin metode yang bersumber dari Alquran ialah metode amtsal, metode qishah qurani, metode ibrah mauidzah, metode targhib-tarhib, metode uswah hasanah dan metode hiwar jadali (Tim Redaksi Nuansa Aulia, 2008). (4) Penerapan Media Edukatif: berdasarkan hasil tindak lanjut dari program supervisi ini, pendidik dituntut untuk menerapkan media edukatif untuk memudahkan siswa dalam memahami isi materi. Media merupakan alat bantu yang sangat bermanfaat bagi para siswa dan pendidik dalam proses belajar dan mengajar. Dengan adanya media pembelajaran, peran pendidik menjadi semakin luas (Dina, 2011). (5) Membuat Program Evaluasi dan Pengayaan: berdasarkan hasil tindak lanjut dari program supervisi ini, pendidik dituntut untuk mengadakan program evaluasi dan pengayaan dari hasil pedagogik spiritual yang diterapkan oleh pendidik di kelas maupun di luar kelas. Evaluasi dalam pendidikan Islam merupakan cara atau teknik penilaian terhadap tingkah laku anak didik berdasarkan standar perhitungan yang bersifat komprehensif dari seluruh aspek-aspek kehidupan mental-psikologis dan spiritual-religius, karena manusia bukan saja sosok pribadi yang tidak 
hanya bersikap religius, melainkan juga berilmu dan berketerampilan yang sanggup beramal dan berbakti kepada Tuhan dan masyarakatnya (Syihabuddin, 2016). Dalam hal ini evaluasi dan program pengayaan diharapkan dapat memenuhi prinsip evaluasi yang digambarkan dalam AlQuran, dan praktek yang dilakukan Rasulullah, mengutip apa yang pernah ditulis oleh (Ramayulis, 2011) sejatinya evaluasi berfungsi untuk menguji daya kemampuan manusia beriman terhadap berbagai macam problema kehidupan yang dihadapinya dan untuk mengetahui sejauh mana atau sampai dimana hasil pendidikan spiritual mampu diaplikasikan dalam kehidupan sehari-hari seperti apa yang telah dicontohkan Rasulullah contoh melalui sunahnya. Dengan demikian peningkatan kompetensi pedagogik spiritual pendidik mampu menciptakan sekolah kondusif, pembelajaran efektif, serta menghasilkan peserta didik yang berkarakter Islami.

\section{KESIMPULAN}

Penelitian ini secara umum menghasilkan kesimpulan bahwa kemampuan manajerial kepala sekolah dalam melakukan supervisi dapat meningkatkan kompetensi pedagogik spiritual pendidik, adapun secara khusus: pertama, strategi supervisi kepala sekolah untuk meningkatkan kompetensi pedagogik spiritual pendidik melalui penerapan supervisi akademik dapat berjalan secara efektif dengan keterampilan konseptual, interpersonal dan teknik. Kedua, pendekatan supervisi kepala sekolah untuk meningkatkan kompetensi pedagogik spiritual pendidik dengan menggunakan pendekatan langsung, tidak langsung dan kolaboratif. Dalam hal ini yang diteliti berkaitan dengan menguasai teori belajar dan prinsip-prinsip pembelajaran yang mendidik, mengembangkan kurikulum yang terkait dengan mata pelajaran yang diampu, serta memanfaatkan teknologi informasi dan komunikasi dalam pembelajaran yang diampu. Ketiga, implikasi bagi sekolah yakni terciptanya suasana sekolah yang kondusif dan pembelajaran yang efektif dengan memperbaharui karakter kurikulum, kebijakan serta aturan yang mengandung nilai-nilai spiritual. Kemudian implikasi bagi pendidik ialah terciptanya suasana sekolah yang kondusif dan pembelajaran yang efektif dengan mendisiplinkan administrasi, memperluas sumber dan bahan ajar, memanfaatkan teknologi dan informasi, menerapkan metode qur'ani, menerapkan media edukatif, membat program evaluasi dan pengayaan yang berfungsi untuk meningkatkan kulitas spiritual peserta didik.

\section{DAFTAR PUSTAKA}

Arikunto, S. (2003). Prosedur Penelitian Suatu Pendekatan Praktek. Rineka Cipta. 
Azra, A. (1999). Pendidikan Islam: Tradisi dan Modernisasi Menuju Millenium Baru. Logos Wacana Ilmu.

Baharuddin. (2016). Kepemimpinan Kepala Sekolah dalam Era Otonomi Pendidikan. Jurnal AlHarakah, 63(01), 10-20.

Buckley, P., \& Irawan, I. (2015). The Scientific Paradigm of Islamic Education Management: Phenomenology Perspective. Jurnal Pendidikan Islam, 2(1), 1-29. https://doi.org/10.15575/jpi.v2i1.701

Danim, S. (2002). Inovasi Pendidikan dalam Upaya Peningkatan Profesionalisme Tenaga Kependidikan. Pustaka Setia.

Dian, D., \& Prayoga, A. (2019). Supervisi Akademik Kepala Madrasah di Madrasah Aliyah Darussalam Sumedang. Briliant: Jurnal Riset Dan Konseptual, 04(04), 548-558. https://doi.org/10.28926/briliant.v4i4.413

Dina, I. (2011). Ragam Alat Bantu Media Pembelajaran. Diva Press.

Engkoswara, \& Komariah, A. (2010). Administrasi Pendidikan. Alfabeta.

Fathoni, A. (2006). Metodelogi Penelitian dan Teknik Penyusunan Skipsi. Rineka Cipta.

Gluek, \& William. (1998). Manajemen Strategis dalam Kebijakan Perusahaan. Erlangga.

Hadi, S., \& Andi. (2004). Metode Research (Ed.II). Remaja Rosdakarya.

Hamalik, O. (1994). Sistem Pembelajaran Jarak Jauh dan Pembinaan Ketenagaan. Trigenda Karya.

Ibrahim, N. S. (2001). Penelitian dan Penilaian Pendidikan. Sinar Baru.

Kaffah, D. Q., \& Prayoga, A. (2019). Kepemimpinan soft Power Kepala Sekolah Di SMP Islam. In Jurnal Al-Mau'izhoh (Vol. 1, Issue 2).

Moleong, L. J. (2012). Metode Penelitian Kualitatif (cet ke-30). Remaja Rodakarya.

Mulyasa, E. (2013). Menjadi Kepala Sekolah Profesional. PT Remaja Rosda Karya.

Nata, A. (2010). Ilmu Pendidikan Islam. Kencana Prenada Media Group.

Piet, S. (2010). Konsep Dasar dan Teknik Supervisi Pendidikan. Rineka Cipta.

Prasojo, L. D., \& Sudiyono. (2011). Supervisi Pendidikan. Gava Media.

Prayoga, A., Dian, D., \& Masrul Anwar, A. (2020). Strategi Peningkatan Kompetensi Pedagogik Pendidik Dalam Penyusunan Rencana Program Pembelajaran. In Journal of Chemical Information and Modeling (Vol. 6, Issue 1). https://doi.org/10.1017/CBO9781107 415324.004

Prayoga, A., \& Irawan, I. (2020). Manajemen Strategi Dalam Pengembangan Budaya Akademik Madrasah Muallimin. In TA"LIM: Jurnal Studi Pendidikan Islam (Vol. 3, Issue 1). https://ejournal.unugha.ac.id/index.php/pancar/article/view/66

Prayoga, A., \& Supiana. (2020). Supervisi Akademik Kepala Madrasah. INOVATIF: Jurnal Penelitian Pendidikan, Agama Dan Kebudayaan, 06(01), 105-124. http://www.jurnal.staih.ac.id/index.php/inovatif/article/view/106

Purwanto, M. N. (1984). Administrasi dan Supervisi Pendidikan. Remaja Rosda Karya.

Ramayulis. (2011). Ilmu Pendidikan Islam. Kalam Mulia.

Sahmudin, S., \& Prayoga, A. (2019). Meningkatkan Kompetensi Pedagogik Pendidik Dalam Pembelajaran Melalui Supervisi Akademik. Al-Mau'izhoh, 1(2), 12-22. http://www.jurnal.unma.ac.id/index.php/am/article/view/1673

Sanusi, H. P. (2013). Peran Guru PAI dalam Pengembangan Nuansa Religius di Sekolah. Jurnal Pendidikan Agama Islam At-Ta'lim, 11(02), 137-143.

Sondang P, S. (2015). Filsafat Administrasi Edisi Revisi (Cet ke-8). Bumi Aksara.

Suhertian, A. (2008). Supervisi Pendidikan dalam Rangka Pengembangan Sumber Daya Manusia. 
Rineka Cipta.

Syahiddin. (2009). Menelusuri Metode Pendidikan dalam Al-Quran. CV. Alfabeta.

Syihabuddin. (2016). Pedagogik Spiritual: Telaah Ihwal Landasan Nilai dan Prinsip Pendidikan dalam Perspektif Guru Berprestasi. Konvensi Nasional Pendidikan Indonesia (KONASPI) VIII, 1-8.

Tim Redaksi Nuansa Aulia. (2008). Himpunan Perundang-Undangan RI Tentang Sistem Pendidikan Nasional. Nuansa Aulia.

Tohirin. (2012). Motode Penelitian Kualitatif dalam Pendidikan dan Bimbingan Konsling. Rajawali Pers.

Victorynie, I. (2018). Kompetensi Spiritual Guru dalam Mencapai Tujuan Pendidikan yang Komprehensif. Jurnal Ilmiah Indonesia, 03(11), 92-107. 